\title{
An Evaluation of the Cross-Sectoral Policy Coordination in Latvia
}

\author{
Alise Vitola, Maija Senfelde \\ Riga Technical University \\ Kalnciema str. 6, Riga, LV-1048, Latvia \\ DOI:10.13165/VPA-15-14-2-06
}

\begin{abstract}
Key societal challenges are cross-sectoral and do not correspond to administrative structures. The policy coordination enables synergy or at least prevents overlapping and conflicts of sector policies, which is increasingly important due to growing complexity of many policy issues. The article analyses the notion of policy coordination and offers a classification of the types of policy coordination. It also evaluates the policy coordination in Latvia by analysing national legislation, policy papers and the opinion of public administration officials. Consequently, the article proposes solutions for increasing the policy coordination in Latvia.
\end{abstract}

Keywords: policy coordination, national development strategy, strategic planning in the public sector, centre of government.

Raktažodžiai: politikos koordinavimas, nacionalinès plètros strategija, strateginis planavimas viešajame sektoriuje, valdymo centras.

\section{Introduction}

Key societal challenges, e.g., demographic change, climate change, technological change and the economic and fiscal policy challenges in the period of a moderate economic growth or even downturn, are cross-sectoral and do not correspond to administrative structures $[1,2,18,19,20]$. A smooth policy coordination enables synergy or at least prevents overlapping and conflicts of sector policies $[2,4,11$, 20]. However, it also presents a threat to sectors and their stakeholders which have attained and reproduced a specific balance of power [10]. By encouraging more 
coordination, also the opposite may happen when sectors squeeze out opportunities for cooperation in order to protect their core functions [20].

Previous reports on the policy coordination in Latvia stress important deficiencies - inconsistency and the lack of synergy between sector policies and an insufficient link between policy planning and investment planning processes $[5,23,24,25,26]$. However, the public administration has taken steps to improve the cross-sectoral policy coordination in Latvia, including the development of the National Development Plan 2014-2020 and the establishment of a central policy coordination unit under the direct supervision of the Prime Minister - the Crosssectoral Coordination Centre.

The aim of this paper is to evaluate the current state-of-art of cross-sector policy coordination in Latvia. The subject of the paper is the cross-sectoral policy coordination in Latvia. The methods used are document analysis (covering scientific articles, research papers and policy papers), comparative statistical analysis and a survey on the cross-sectoral policy coordination in Latvia. The survey covers 40 officials in line ministries in Latvia to find out their views on cross-sectoral policy coordination. It included questions on the importance of the cross-sectoral policy coordination, on the usefulness of the instruments of policy coordination (both formal and informal), on the preferable ways to coordinate sector policies in the medium-term and on the necessity and capacity to involve regional and local level in sector policy planning.

The structure of the paper is as follows. Section 2 analyses various aspects of the policy coordination and offers a classification of the types of policy coordination. Section 3 outlines current trends in cross-sector policy coordination in Latvia. Section 4 analyses the results of the survey of the line ministries. The last section concludes and suggests perspectives for the cross-sector policy coordination in Latvia.

\section{The notion of the policy coordination}

The policy coordination is a continuous procedural value that aims at (1) avoidance or at least minimisation of duplication, overlapping and inconsistency of government policies, as well as bureaucratic and political conflict; (2) promotion of comprehensive and coherent whole government perspective and set of priorities instead of narrow and sectoral perspectives $[2,4,11]$.

Policy coordination is not an all of nothing matter; it can be limited in terms of domains and time. "Policy coordination as such does not absolutely need a wholegovernment perspective, but it implies at a minimum a perspective that is agreed upon by a number of political actors" [4, p. 230-231]. The same organisations in some domains may act independently, and in others in a close cooperation with other organisations. Consequently, different domains require different levels of coordination capacities. If a simple method of coordination is sufficient, there is no need to use more sophisticated and complex methods $[4,11]$. 
Changes to enhance policy coordination do not need all to be structural, as changes in the culture of government are essential [3]. If the politicians and public administration officials do not trust each other, the probability of mutual coordination decreases significantly. The low level of trust and social capital makes the policy coordination an even more challenging task for post-soviet countries, including Latvia.

Table 1. Social capital in EU-27, Latvia, Estonia and Finland [7, 21, 22]

\begin{tabular}{|l|c|c|c|c|c|}
\hline Indicator & Year & Latvia & EU-27 & Estonia & Finland \\
\hline Trust level in national parliament & 2011 & $14 \%$ & $27 \%$ & $40 \%$ & $58 \%$ \\
\hline Trust level in national government & 2011 & $19 \%$ & $24 \%$ & $49 \%$ & $56 \%$ \\
\hline Trust level in most people & 2005 & $15 \%$ & $30 \%$ & $33 \%$ & $61 \%$ \\
\hline $\begin{array}{l}\text { Satisfaction with the way public } \\
\text { administration runs }\end{array}$ & 2013 & $26 \%$ & $40 \%$ & $58 \%$ & $66 \%$ \\
\hline
\end{tabular}

Trust in national parliament and government is low, especially in comparison to its northern neighbours Estonia and Finland, which experience in policy coordination could be used in Latvia due to similar political construction - coalition governments and weak premiership. Low trust in public administration corresponds to a low level of social capital in society and low satisfaction with the way public administration runs (Table 1).

We define policy coordination as a continuous process of merging, balancing and prioritising objectives of different policy domains, e.g., economic, social, cultural and ecological objectives in order to enable synergy. We also believe that the preferable level of policy coordination depends on the sophistication of the issue and that the informal aspects (e.g., organisational culture and social capital) play a crucial role in the process of policy coordination.

Based on the literature analysis, a classification of various types of policy coordination is proposed in Figure 1.

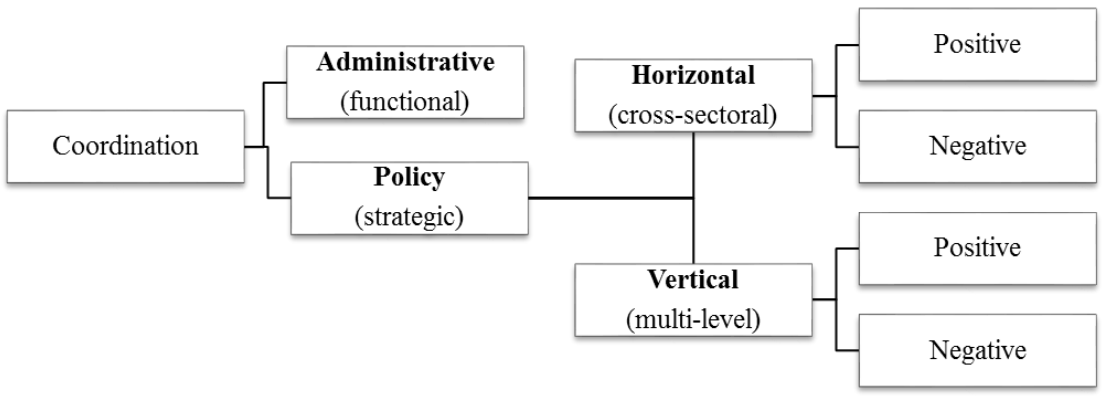

Figure 1. Types of policy coordination

Source: developed by the authors 
Policy coordination includes both administrative (functional) coordination and policy (strategic) coordination. Administrative coordination is concerned with ensuring smooth cooperation within and between organisations, whereas policy (strategic) coordination is about the development of consistent policies, the determination of a set of priorities and formulation of strategies to implement them $[2,4]$. Administrative coordination is a crucial precondition for strategic coordination, as perspectives and strategies cannot be drafted and implemented without administrative support. Moreover, emphasis should be put on the political and administrative balance, especially in countries with coalition governments, weak premiership and an insignificant role of national parliament in policy making and implementation.

We distinguish vertical and horizontal policy coordination. Horizontal or cross-sectoral policy coordination focuses on managing policies across the sectors. Horizontal policy coordination means that policies tend to integrate with each other $[18,19]$. Vertical or multi-level policy coordination focuses on the relationship between the levels of government from policy making to policy implementation (e.g., ministry and agency level or national and local level). It ensures that policy is translated into organisational responsibilities and budget implications [3, 19].

Horizontal and vertical policy coordination includes positive and negative policy coordination. Negative policy coordination aims at avoiding or hiding disagreements among line ministries or levels of government. It might be done by setting a clear jurisdiction on the domains of institutions, by exchanging information and making consultations with other institutions in order to avoid or hide disagreements, etc. A third party (e.g., the Prime Minister or the centre of government) might be involved in resolving conflicts if ministries are unable to reach an agreement voluntarily. If no third party is involved in managing such conflicts, it can happen that no decision is taken at all.

Positive policy coordination aims at seeking consensus on policies and induces synergy. Institutions voluntarily search for an agreement on common priorities and government-wide perspective, e.g., by introducing inter-ministerial committees, jointly drafting policy papers or managing policy-programmes. A centre of government may play an important role in establishing priorities and main lines of policies [11].

However, literature is sceptical about voluntary policy coordination actions by ministries. Cross-sectorality presents a threat to sectors and its stakeholders because sectors have gained a specific balance of power to assign rights and benefits. As distributional interests are very strong "win-win", Pareto-optimal solutions are required. To overcome it, information (persuasion) and power in a form of pressure or financial incentives may be used $[4,10]$. 


\section{Cross-sectoral policy coordination in Latvia}

In order to evaluate the current state-of-art of the policy coordination in Latvia, we will look at the formal policy planning system, the institutional framework for sector policy coordination and, last but not least, - the informal aspects of the policy coordination expressed by the public officials.

The boundary-spanning principle (expansion of activities beyond the frameworks of individual sectors and formal borders of a state) is stressed in the formally most important policy papers - Conceptual document "A Growth Model for Latvia: People First", Sustainable Development Strategy of Latvia until 2030, National Development Plan 2017-2013 and National Development Plan 2014-2020 $[6,13,16,17]$.

The national legislation states a clear hierarchy and interdependence among different term and level policy papers (Figure 2) $[14,15]$. Firstly, policy documents are subordinated according to the time-limit - medium-term policy documents are subordinated to long-term policy documents, and short-term policy documents are subordinated to medium-term policy documents. Long-term policy documents cover a time period of seven to 25 years, medium-term policy documents - three to seven years, short-term policy documents - up to three years. Long-term and medium-term documents are strategic vision documents, whereas short-term policy documents have a more operational nature, because their time-limit corresponds to the threeyear budget planning cycle in Latvia.

Secondly, policy documents are subordinated according to the level of public administration in which they operate - regional level policy documents are subordinated to the national level policy documents and local level policy documents are subordinated to the regional level policy documents. The national level policy documents include cross-sectoral and sector strategies, guidelines and plans developed by the ministries and other central institutions. The regional and local level strategies and programmes are produced by the planning regions (government bodies dealing with regional planning issues) and local municipalities, respectively. Of course, the principle of subsidiarity should be also taken into account regarding the subordination of these documents by facilitating policy planning as closely as possible to the citizen. 


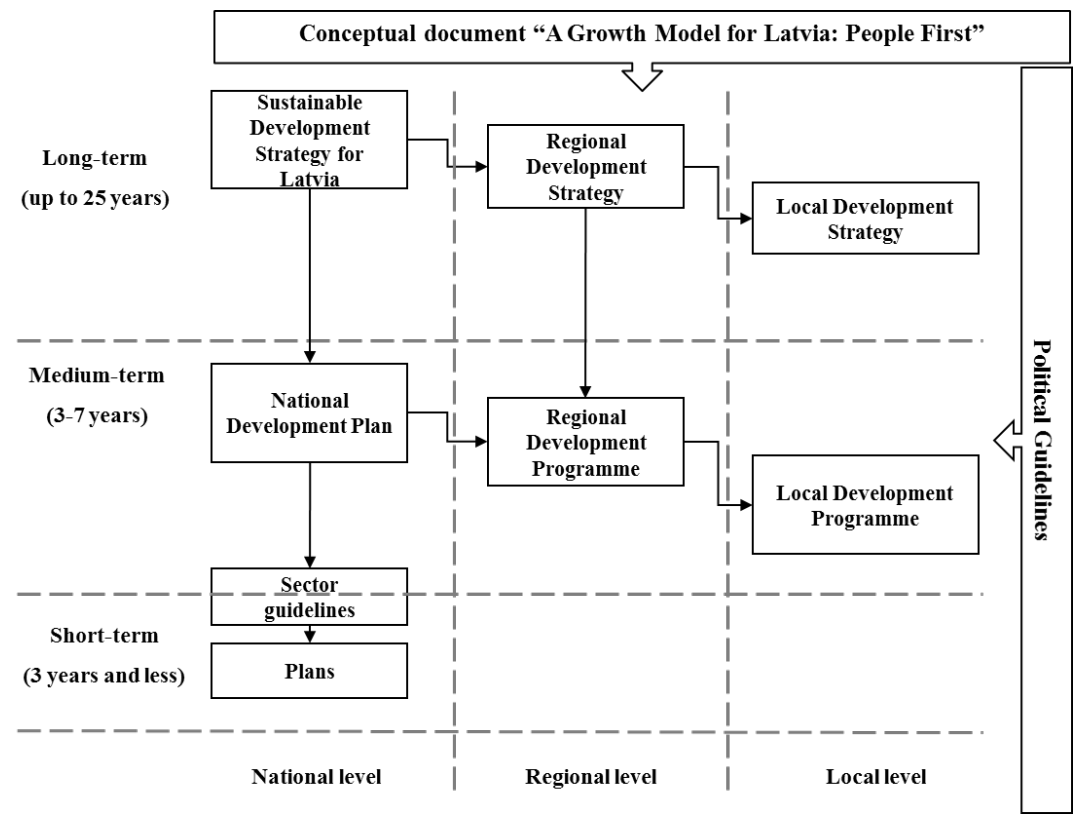

Figure 2. Hierarchy and interdependence among policy papers in Latvia

Source: developed by the authors based on $[14,15]$

Moreover, all types of policy documents should be in line with the political guidelines - the government declaration and government action plans. If the political guidelines are not corresponding to the policy documents, the policy documents should be updated to ensure compliance or vice versa.

Last but not least, to encourage consistency and synergy of the sector policies in solving cross-sectoral challenges, Latvia has developed a long-term policy document called The Sustainable Development Strategy for Latvia until 2030 and a mediumterm policy document called The Latvia's National Development Plan 2014-2020. These documents are the hierarchically highest policy papers. It means that all other policy documents should be consistent with them and facilitate the implementation of the strategy stated in The Sustainable Development Strategy and The National Development Plan.

Despite of the clear hierarchy of policy documents set in the national legislation, previous evaluation reports drafted by the public officials, external experts and researchers have stressed such policy planning deficiencies as inconsistency and the lack of synergy between sector policy documents and an insufficient link between policy planning process and investment planning processes (first of all, regarding the 
planning of European Union funds' investments that are the major source of public investment in Latvia, but also regarding the national budget allocation) $[5,23,24$, $25,26]$.

Cross-sectoral policy papers, such as The Sustainable Development Strategy and The National Development Plan in Latvia, may play an important role in enhancing policy coordination among sectors and levels of public administration. At the same time, a certain level of policy coordination capacities has to be already there before drafting and implementing such documents. Otherwise political energies may be exhausted in drafting policy documents that cannot be implemented because the capacity of policy coordination is too weak [11].

The unsatisfactory implementation of the previous National Development Plan 2007-2013 (hereinafter - NDP2013) shows that policy planning was not integrated and coordinated to implement a united mid-term development strategy $[5,23]$. The NDP2013 was drafted in order to set strategic development goals and priorities for public investments for a sustainable and balanced development of the state and its territories. It should have been financed by the European Union programmes, which would be drafted according to the NDP2013, and national programmes, financed by central and local government $[8,12]$.

In practise, the NDP2013 included rather broad recommendations and no specific instruments for its implementation were designed. Moreover, it did not include all sectors, e.g., agriculture and foreign affairs were left out. Consequently, public administration officials revealed that they did not use the NDP2013 in sector policy making or referred to it formally and suggested that the NDP2013 most likely did not change anything in their policy domain. Some officials even argued that the NDP2013 was never seriously meant to be implemented [23]. Consequently, the NDP2013 became an illustration of the insufficiently developed policy coordination system in Latvia.

To overcome these problems in the cross-sectoral policy coordination, at the end of 2011 the government established a special central policy coordination unit - the Cross-Sectoral Coordination Centre - to develop the National Development Plan 2014-2020 (hereinafter - NDP2020) and to ensure the cross-sectoral policy coordination. The NDP2020 was developed by the public officials in close cooperation with the politicians of the coalition parties, thus encouraging a political involvement and will to ensure the implementation of the strategy. The NDP2020 was discussed also with the opposition parties, thus demonstrating an open policy making process. Numerous public consultations also took place. Consequently, the NDP2020 was approved by the National Parliament at the end of 2012 with 81 parliament members voting for and 7 parliament members abstaining.

Whenever aiming to improve policy coordination, it is crucial to evaluate the current state and art of coordination capacities and foresee corresponding investments in their improvement. As argued by Metcalfe, "often political energies are exhausted in process of setting objectives and defining missions which cannot be fulfilled 
because more basic but less glamorous aspects of the policy coordination process are too weak to support the weight of large political ambitions" [11, p. 288].

\section{Results of the survey of sector officials in Latvia}

Taking into account the before mentioned Latvian government's efforts to improve the cross-sectoral policy coordination process, it is important to evaluate the current level of policy coordination in Latvia, as well as to analyse various aspects of policy coordination instruments and approaches.

In 2012, we surveyed 40 officials in sectoral ministries to find out their views on cross-sectoral and multi-level policy coordination. The survey included questions on the importance of cross-sectoral policy coordination, on the usefulness of the instruments of policy coordination (both formal and informal), on the preferable ways to coordinate sector policies in the medium-term and on the necessity and capacity to involve regional and local level in sector policy planning.

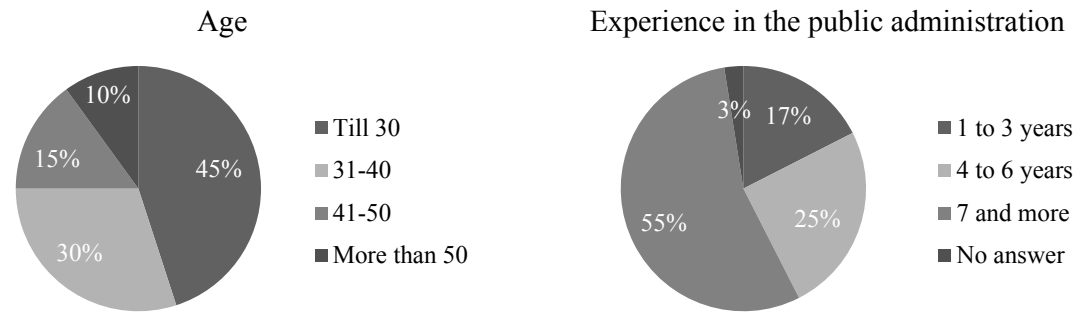

Figure 3. The experience in public administration and age structure of the respondents

The age structure of the respondents shows that most of them are relatively young - in their twenties or thirties. However, more than a half of the respondents have worked in the public administration more than seven years, one quarter of the respondents - more than three years (Figure 3). It can be concluded that they are experienced enough to evaluate the currents trends of cross-sectoral and multi-level policy coordination in Latvia based on their professional experience.

Regarding the significance of the cross-sectoral policy coordination, the majority of the respondents agree that policy coordination is important for the development of their sector (very important $-75 \%$, fairly important $-25 \%$ ) and the development of the country in general (very important $-85 \%$, fairly important $-15 \%$ ).

In order to measure the level of policy coordination, the respondents were asked about the frequency of different policy coordination activities. The results show that most often the officials exchange information and consult with each other. Sometimes, they also voluntarily search for an agreement but the likelihood of the arbitration by the third side (e.g., prime minister) or an integration of sectoral policies 
is rather low. It suggests that currently the level of policy coordination is still rather low (Figure 4).

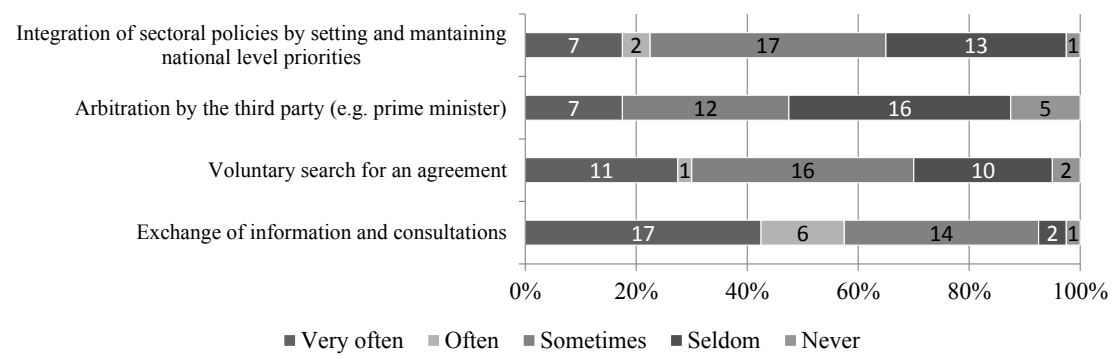

Figure 4. The level of policy coordination

Informal policy coordination instruments seem to be more useful than policy documents and formal procedures. Interestingly, policy documents are evaluated as more useful than the declaration of government which states the policy priorities of the government (Figure 5).

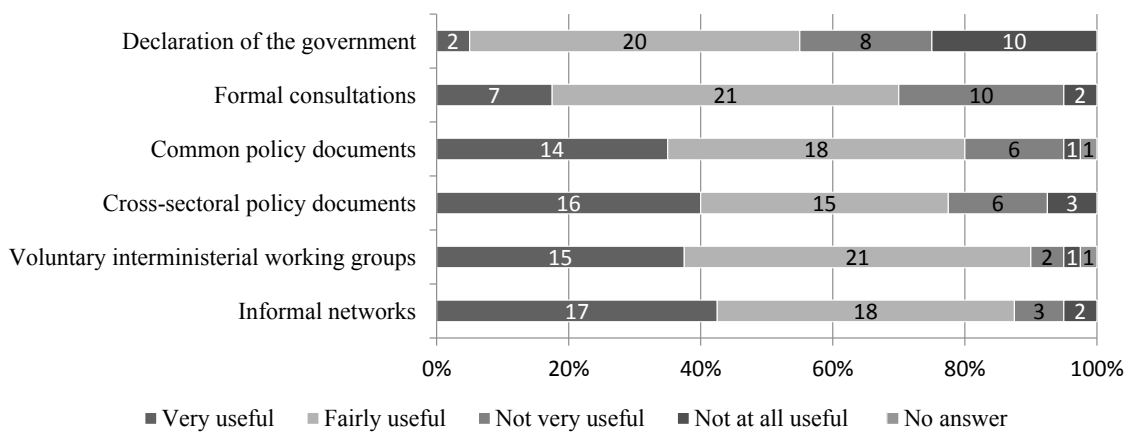

Figure 5. The usefulness of policy coordination instruments

Moreover, the operation of the ministries depends much more on the minister's political opinion and the topicalities in national and European Union level than on the policy papers in force. The planning process of the European Union funded programmes is also a very important aspect as the European Union funds form the majority of the public investment in Latvia, and the policy papers lack direct link with the allocation of the national budget resources (Figure 6). 


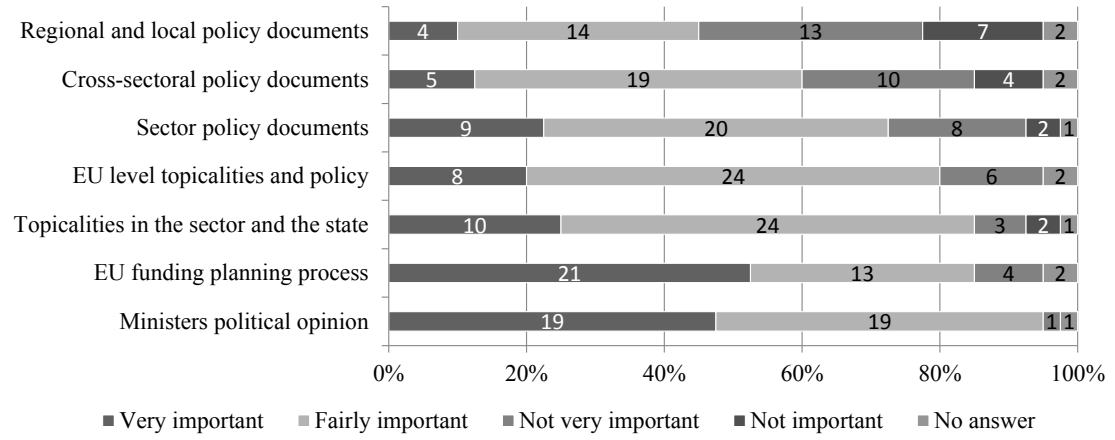

Figure 6. The aspects that influence the operation (legislation, investment, subsidies) of the ministry

Last but not least, more than a half of the respondents (54\%) think that crosssectoral and multi-level policy coordination should be facilitated by special projects or programmes in particular fields rather than by implementing a comprehensive wholegovernment strategy $(15 \%)$. At the same time, a considerable part of the respondents (25\%) does not believe that a form more complicated than consultations with other ministries could be successfully implemented in the coming years (Figure 7).

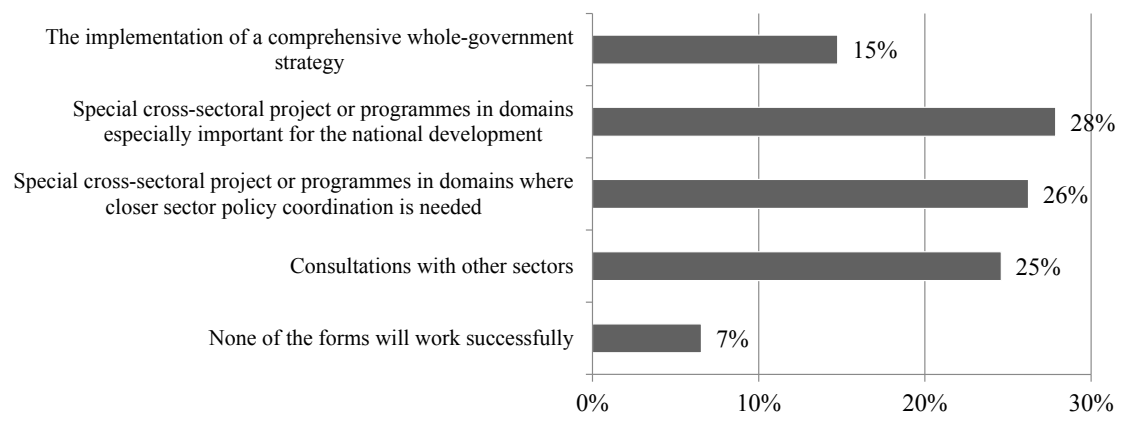

Figure 7. The forms of policy coordination that could be successfully implemented in the coming years

The respondents were asked also about their opinion about the multi-level policy coordination. The majority of the officials agreed that the involvement of the regional and local level in sector policy planning is very or fairly important (Figure 8). 


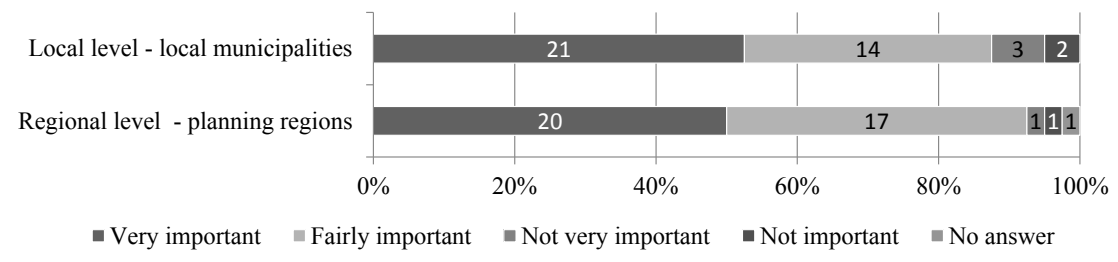

Figure 8 . The need to involve regional and local level in policy planning

However, currently the importance of regional and local policy documents in sector policy making is rather low. Only $45 \%$ of the respondents agreed that regional and local policy documents have had some effect on the sectoral policy.

The gap between the desirable and the actual situation can be explained with the very sceptical attitude towards the planning capacity of the regions and municipalities. Only $21 \%$ of the respondents assessed the capacity of local municipalities to participate in sector policy planning as fairly sufficient. The capacity of planning regions was assessed higher $-8 \%$ evaluated it as sufficient and $33 \%$ as fairly sufficient (Figure 9).

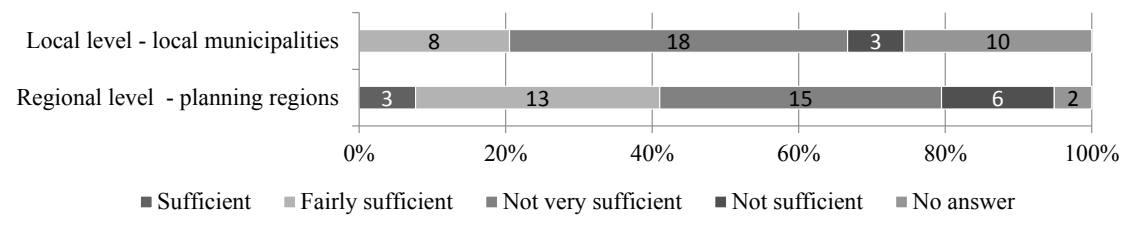

Figure 9. The capacity of the regional and local level to involve in policy planning

Still, the majority of the officials $(72 \%)$ agreed that the decentralisation of policy making to regional level would increase the level of cross-sectoral policy coordination. At the same time, the decentralisation to local level is perceived sceptically as the majority of the respondents $(69 \%)$ did not agree that it would increase the level of sector policy integration (Figure 10).

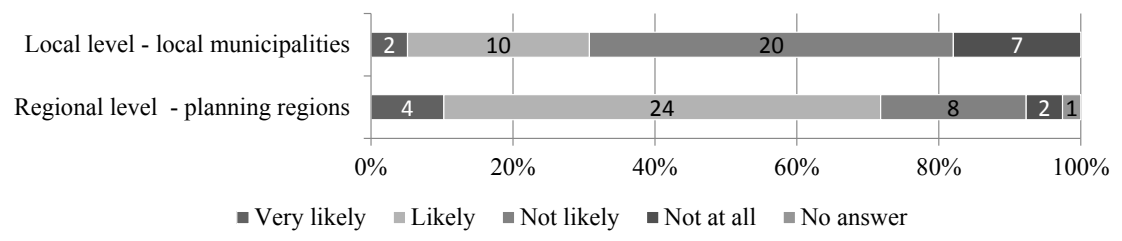

Figure 10. The likelihood that the decentralisations of the policy making to the regional and local level would increase the cross-sector policy coordination 
Last but not least, some of the respondents also gave additional comments, stressing the need to actually implement the approved policy documents by assigning responsibility and allocating the financing. Also, a simplification of the policy planning process was mentioned in order to diminish the administrative burden to public officials. Furthermore, a need to educate politicians about the policy making process was suggested. Regarding the fact if the cross-sectoral policy coordination was sufficient, contrary views emerged: some of the respondents argued that the current state of policy coordination is sufficient, whereas some stressed the need to strengthen the cross-sectoral policy coordination function.

\section{Conclusions and suggestions}

1. The research suggests that the current level of policy coordination in Latvia is rather low. In order to increase it, the administrative discussion so far has focused on its formal side - policy documents, procedures and institutions. New documents have been drafted and new institutions established. Undoubtedly, it will help to mitigate some of the policy coordination problems.

2. However, our research shows that informal aspects play a very important role in policy coordination processes. Therefore, to raise the capacity of the cross-sectoral policy coordination, one should encourage networking in public administration by promoting the exchange of experience, shaping an informal network of officials, introducing rotation of senior staff, etc. More emphasis should be put on the values that promote serving the collective interests of government, e.g., during the yearly evaluation of the work of officials, the opinion of colleagues in related ministries could be taken into account.

3. As the current level of policy coordination in Latvia is rather low, we suggest that Latvia should focus its policy coordination efforts on enhancing policy coordination in particular domains that demand a strong cross-sectoral approach, e.g., productivity, employment, policies to increase births, etc. A limited number of domains to coordinate will increase the probability of success. Thus, it could serve as an example of good practice and decrease the current scepticism in public administration. The central policy coordination unit in Latvia - the Cross-sectoral Coordination Centre - could act as a coordinator in implementing such cross-sectoral policies.

4. The financial motivation for strengthening the cross-sectoral policy coordination is a crucial precondition as it counteracts distributive interests of sectors. Therefore, European Union funds and national budget resources could be allocated to cross-sectoral and multi-level programmes or projects, thus offering a "carrot" for a closer cooperation. It would eventually translate into higher trust among stockholders.

5. Further research should focus on the informal aspects of the cross-sectoral policy coordination and include pilot actions to increase networking, trust and cooperation of the public officials representing different sectors, as well as politicians. The success of these actions should be evaluated in order to find and 
develop the most appropriate measures. Such research would require a strong longterm cooperation among officials, politicians and researchers; therefore, we would advise to use the action research approach similar to the one used by Karlsen and Larrea in the Gipuzkoa Sarean project in Spain [8].

\section{Bibliography}

1. Bossaert, D., and Demmke, C. The Impact of Demographic Change and Its Challenges for the Workforce in the European Public Sectors: Three Priority Areas to Invest in Future HRM. European Institute of Public Administration Working paper, 2012/W/01, 2012.

2. Boston, J. The Problems of Policy Coordination: The New Zealand Experience. Governance: An International Journal of Policy and Administration. 1992, 5(1): 88-103.

3. Bouckaert, G., Ormond, D., and Peters, G. A. Potential Governance Agenda for Finland. Finland: Ministry of Finance, 2000.

4. Braun, D. Organising the Political Coordination of Knowledge and Innovation Policies. Science and Public Policy. 2008, 35(4): 227-239.

5. Cabinet of Ministers of Republic of Latvia. About the Implementation of National Development Plan 2007-2013 in the Year 2007. 2008.

6. Cabinet of Ministers of Republic of Latvia. National Development Plan 2007-2013. 2006.

7. Eurobarometer 76. Public Opinion in the European Union. Eurostat, 2011.

8. Karlsen, J., and Larrea, M. Territorial Development and Action Research: Innovation through Dialogue. Farnham:Gower, 2014.

9. Karnitis, E., and Kucinskis, M. Strategic Planning and Management of National Development Processes in Latvia. Journal of Business Economics and Management. 2009, 10(1): 3-13.

10. Krott, M., and Hasanagas, N.D. Measuring Bridges between Sectors: Causative Evaluation of Cross-Sectorality. Forest Policy and Economics. 2006, 8: 555-563.

11. Metcalfe, L. International Policy Co-ordination and Public Management Reform. International Review of Administrative Sciences. 1994, 60: 271-290.

12. Ministry of Regional Development and Local Government of Republic of Latvia. Methodology for Drafting National Development Plan. 2004.

13. National Parliament of Republic of Latvia. A Growth Model for Latvia: People First. 2006.

14. National Parliament of Republic of Latvia. Law on Development Planning System. 2008.

15. National Parliament of Republic of Latvia. Law on Territorial Development. 2011.

16. National Parliament of Republic of Latvia. National Development Plan 2014-2020. 2012.

17. National Parliament of Republic of Latvia. Sustainable Development Strategy of Latvia until 2030. 2010.

18. Pelkonen, A. The Problem of Integrated Innovation Policy: Analysing the Governing Role of the Science and Technology Policy Council of Finland. Science and Public Policy. 2006, 33(9): 669-680.

19. Pelkonen, A., Teräväinen, T., and Waltari, S.-T. Assessing Policy Coordination Capacity: Higher Education, Science, and Technology Policies in Finland. Science and Public Policy. 2008, 35(4): 241-252. 
20. Pollitt, C. Future Trends in European Public Administration and Management: An Outside-in Perspective. Coordinating for Cohesion in the Public Sector of the Future (COCOS) Report Work Package 8, 2014.

21. Special Eurobarometer 223. Social Capital. Eurostat, 2005.

22. Special Eurobarometer 408. Social Climate. Eurostat, 2013.

23. State Chancellery. The Evaluation and Recommendations for the Process of Drafting, Implementing and Evaluating National Development Plan 2007-2013. 2011.

24. Vitola, A., and Senfelde, M. Analysis of Policy Coordination System in Latvia Using Institutional Theory. The 7th International Scientific Conference "Business and Management 2012", 2012, p. 783-790.

25. Vitola, A., and Senfelde, M. Institutional Arrangements of National Development Plan 2007-2013 - Intention, Practice and Future Prospects. Scientific Journal of RTU. Sustainable Spatial Development. 2011, 2(14): 63-71.

26. Vitola, A., and Senfelde, M. The Optimization of National Development Planning System as a Precondition for Competitiveness and Sustainability of National Economy. Economics and Management. 2010, 15: 325-331.

\section{Alise Vitola, Maija Senfelde}

\section{Tarpsektorinės politikos koordinavimo vertinimas Latvijoje}

\section{Anotacija}

Esminiai iššūkiai visuomenei yra iš dalies sutampantys ir neatitinka administracinių struktūrų. Politikos koordinavimas užtikrina sinergiją ar bent jau užkerta kelią painiavai ir konfliktams tarp įvairių sričių politikų, o tai labai svarbu turint omeny vis didejjantị sprendžiamų klausimų painumą. Parašytuose darbuose analizuojama politikos koordinavimo sąvoka ir siūloma politikos koordinavimo tipų klasifikacija. Taigi galima įvertinti politikos koordinavimo lygmenį Latvijoje, pasitelkus įstatymus, politikos dokumentus ir perpratus valstybę valdančių darbuotojų požiūrị. Toliau yra siūlomi sprendimai politikos koordinavimo pajègumams Latvijoje stiprinti.

Alise Vitola - Rigos technikos universiteto Inžinerinès ekonomikos ir vadybos fakulteto Teritorinès plètros valdymo ir miestų ekonomikos katedros ekonomikos magistré, doktorantè ir mokslinè asistentè.

E. paštas alise.vitola@rtu.lv

Maija Senfelde - Rigos technikos universiteto Inžinerinès ekonomikos ir vadybos fakulteto Teritorinès plètros valdymo ir miestų ekonomikos katedros ekonomikos profesorè, daktarè.

E. paštas maija.senfelde@rtu.lv

Alise Vitola, Master of Economics, Riga Technical University, Faculty of Engineering Economics and Management, Department of Territorial Development Governance and Urban Economics, Doctoral Student and Scientific Assistant.

E-mail: alise.vitola@rtu.lv

Maija Senfelde, Doctor of Economics, Riga Technical University, Faculty of Engineering Economics and Management, Department of Territorial Development Governance and Urban Economics, Head of the Department and Professor.

E-mail: maija.senfelde@rtu.lv

Straipsnis įteiktas redakcijai 2015 m. sausio mèn.; recenzuotas; parengtas spaudai 2015 m. birželio mèn. 